\title{
THE PHONOLOGICAL PROCESS OF SEMIVOWEL INSERTION IN BAHASA INDONESIA
}

\author{
Kartika Eva Rahmawati, Agus Subiyanto \\ Universitas Diponegoro (UNDIP), Semarang, Indonesia \\ E-mail: kartikaevarahmawati@students.undip.ac.id
}

Received: 2021-11-10

Accepted: 2021-12-03

\begin{abstract}
The phonological process shows the changing of sounds and the rules that govern the work. These sound changes can occur in vowels, consonants, and even semivowels. This study focuses on the sound changes that occur in semivowels [y] and [w], especially in Indonesian vocabularies. This study aimed to investigate the quantity of diphthong diversity in Bahasa Indonesia, as the basis for examining the role and patterns of $[\mathrm{y}]$ and $[\mathrm{w}]$ insertion, as well as when [y] and [w] cannot be inserted into some words in Bahasa Indonesia. This study also emphasizes the location where [y] and [w] are inserted by using a spectrogram. The data collection used the observation method. The list of data was taken from Kamus Besar Bahasa Indonesia (KBBI) and pronounced by an Indonesian native speaker. The spoken data are transcribed into the phonetic form using the note-taking technique. The analysis was done through the syllabic structural process based on Schane. The results present that [y] is inserted between the diphthongs $i a, i u, i e, i o, e a$, and $e o$. Then, $[\mathrm{w}]$ is inserted between the diphthongs $u a, u i, u e, u o$, and oa, and the insertion of [y] and [w] does not appear when they meet with the diphthongs ai, au, ae, ao, ei, eu, oi, ou oe. The spectrograms in this study are used to see and present the insertion of $[y]$ and $[w]$.
\end{abstract}

Keywords: semivowels, phonological process, syllabic structural.

\section{Introduction}

Phonology is concerned with sound roles in communication and covers the sounds of language, both in terms of sound production, sound as air vibrations, and audible sounds (all three are examined by phonetics). Chomsky and Halle (1968) found the field of phonology in 1968 , and it is known as generative phonology. The term generative phonology refers to the study of a language's phonological process. As a result, there exist principles for sound modification in the study of generative phonology. The sort of sound itself influences anything that impacts sound alterations. Semivowels are one of the sound kinds. It's a spoken sound that's made up of a vowel that's utilized as a consonant. The sounds [y] and [w] are classified as semivowels.

The writers apply a syllabic structural mechanism to explain the emergence of [y] and [w]. According to Schane (1992), the syllabic structural process influences the relative distribution of consonants and vowels in words. It indicates that vowels and consonants can be added or removed. The insertion of consonants or vowels into a word is an activity that adds consonant and vowel sounds to a word to fit the borrowing language's phonological 
pattern. Meanwhile, deletion of consonants or vowels is an activity that removes vowels and consonants from a sound so that it can be produced normally.

Schane (1992) also explains that after grouping the words, the phonological rules should be formulated as follows.

1. Segment addition is the addition or insertion of a segment to a word. This rule can be formulated as $\varnothing \rightarrow \mathrm{X} / \mathrm{Y} \mathrm{Z}$.

2. Segment lapse is the process of deleting a segment of the word. This rule can be formulated as $X \rightarrow \varnothing / Y Z$.

The decision of the distinctive features in a segment of generative phonology is based on; (1) whether the sound is included in consonants or vowels, (2) if it is consonant and it has a pair (voice and voiceless), then it includes in [-sonorant] and vice versa, (3) if it has an obstruent, then it includes in-cont and vice versa, (4) place of articulation, whether it is in anterior or coronal, (5) and whether it is included invoiced or not.

\section{Literature Review}

The first research was from Arifiani and Subiyanto (2019) who researched about the phonological process of the structural changes of the syllable in the Bayan dialect of the Sasak language. The data shows that the effect of this sound causes changes in the structure of the syllable in the form of sound insertion [r] and $[I]$ in the morphophonemic process of verbs with prefixes / bə- / and insertion of sounds [w] and [y] if verbs get suffixes / -an /. The neutralization of the sound [ə] pronounced into sound [a] is found when the sound of [ə] in the final position meets the sound of [a]. The distinguishing or distinctive character that is neutralized is the [+ tense] feature in the sound [ə] to [-tense] or [+ lax].

The study from Swadana (2018) aims to describe the phonological process and phonological environment of the Jembrana dialect in Bali. The result shows that there are 16 phonological processes of the Jembrana Balinese dialect were found, namely nasal assimilation $/ \mathrm{h} /$, obstruent impregnation $/ \mathrm{p}, \mathrm{b}, \mathrm{t}, \mathrm{d}, \mathrm{c}, \mathrm{f}, \mathrm{k}, \mathrm{g}, \mathrm{s} /$, impregnation $/ \mathrm{s} /$, impregnation $/ \mathrm{h} /$, impregnation $/ \mathrm{h} /$, impregnation $/ \mathrm{k} /$, impregnation $/ \partial /$, insertion $/ \mathrm{n} /$, insertion $/ \mathrm{y} /$, semivowel insertion $/ \mathrm{y} /, \mathrm{w} /$, insertion $/ \partial /$, vocal dissimilation, vocal relaxation, vocal elevation / a /, and vowel reduction / $\mathrm{i} /$.

The previous study about the use of spectrograms to interpret segments of the sound of Old Javanese was conducted by Erawati (2017). This study shows that sound segments are mainly vowels in Old Javanese, such as segments / $\mathrm{u} /$ which are followed by /i/ change to $/ \mathrm{w} /$, sound segments /a/ followed by /i/ that become /e/, and segments /i/ followed by/a/that become $/ y /$. The wave circuit that appears has a slight difference from the previous circuit. The same applies to the duration required for each segment when the segment or syllable is pronounced.

Previous studies have described the sound changes that occur from the insertion of certain sounds in regional languages, such as Balinese dialects, Bayan dialects, and the only Javanese dialects equipped with a spectrogram. The novelty of this study is that the insertion of $[y]$ and $[\mathrm{w}]$ that appear between diphthongs in Bahasa Indonesia has not been researched by the language researchers, while Bahasa Indonesia is used in all levels of Indonesian society. The writers present the occurrences of $[\mathrm{y}]$ and $[\mathrm{w}]$ using a spectrogram. The writers provide an overview of when an Indonesian word can be inserted by [y] and [w] and when it is not inserted. This study also presents the appearance of a glottal stop (?), which makes [y] and $[\mathrm{w}]$ not appear on certain diphthongs, but it is recorded on the spectrogram. The results 
of this study are useful for linguistics students to have a deeper understanding of the rule of sound changing that appears in Indonesian vocabulary.

\section{Research Method}

This study is qualitative research. The data collection method is observation. According to Sugiyono (2014), the observation method is a method of collecting data by observing and recording directly. The writers used the purposive sampling technique by Ary et al. (2010) to choose appropriate data. The source of the data in this study used written data from Kamus Besar Bahasa Indonesia (KBBI). The writers made a list of words in Bahasa Indonesia that consist of different vowels placed side-by-side in one word, for example, [i] and [a] to arrange a word like ceria. Then, the data is pronounced by an Indonesian native speaker to hear the occurrence of $[\mathrm{y}]$ and [w] between the two vowels. The writers used the notetaking technique to write the phonetic transcription.

To present and analyze the data, the writers used the descriptive-qualitative method. The linguistic research is generally included in research with qualitative descriptive methods (Subroto, 2007). This research model is intended to make general conclusions based on phenomena that can be found through data analysis. Next, the writers presented the data by giving examples of some words (they can be nouns, verbs, or adjectives) in Bahasa Indonesia that had the possibility of being inserted by $[\mathrm{y}]$ and $[\mathrm{w}]$ when we pronounce them. Then, the writers wrote the distinctive features for $[y]$ and $[w]$.

To writer the distinctive features, the writers used some symbols such as arrow $(\rightarrow)$ 'becomes', square brackets [...] to indicate that the unit inside is a sound characteristic, and the italic line (/) to show 'something appearing' and the the writers can add reason after the italic line. Meanwhile, to present the appearance of $[y]$ and $[w]$ in a word, the writers used a speech analyzer. A Speech Analyzer is a computer program or software used to analyze acoustics, sounds, phonetics, and sounds that are spoken and sounded. A speech analyzer is also used to find out which part gets the insertion of $[\mathrm{y}]$ or $[\mathrm{w}]$.

\section{Results and Discussion}

Some diphthongs are found in the Indonesian vocabulary. The word can be an adjective, noun, adverb, or verb. The list of diphthongs can be seen in the table below.

\begin{tabular}{|c|c|c|c|c|}
\hline \multicolumn{5}{|c|}{ Diphthongs in Bahasa Indonesia } \\
\hline aa & ia & ua & ea & oa \\
\hline ai & iu & ui & ei & oi \\
\hline au & ie & ue & eu & ou \\
\hline ae & io & uo & eo & oe \\
\hline ao & - & - & - & - \\
\hline
\end{tabular}

Table 1. Diphtongs in Bahasa Indonesia

The data above present that 21 pairs of diphthongs appear in Indonesian words in KBBI. In this study, diphthongs $i i, u u, e e$, and $o o$ are not found in the dictionary. The reason is Bahasa Indonesia has no double vowels in one word. The data of the diphthong's varieties are used to facilitate the writers to look for the words and to determine whether or not the words can bring up the semivowels between the two vowels. 
4.1 The Insertion of $[y]$

\begin{tabular}{|c|c|c|c|}
\hline \multicolumn{4}{|c|}{ The Insertion of $[y]$} \\
\hline No & Diphthongs & Examples & Phonetic Transcriptions \\
\hline 1 & ia & $\begin{array}{l}\text { Bahagia } \\
\text { Indonesia } \\
\text { Euforia }\end{array}$ & $\begin{array}{l}\text { [bahagi`a] } \\
\text { [indonesi }{ }^{\mathrm{y} a} \text { ] } \\
\text { [eufori`a] }\end{array}$ \\
\hline 2 & iu & $\begin{array}{l}\text { Siul } \\
\text { luran }\end{array}$ & $\begin{array}{l}{\left[\mathrm{si}^{y} \mathrm{ul}\right]} \\
{\left[\mathrm{i}^{\mathrm{y}} \mathrm{uran}\right]}\end{array}$ \\
\hline 3 & ie & $\begin{array}{l}\text { Pasien } \\
\text { Efisien }\end{array}$ & $\begin{array}{l}\text { [pasiyen] } \\
\text { [efisiyen] }\end{array}$ \\
\hline 4 & io & $\begin{array}{l}\text { Ion } \\
\text { Biodata }\end{array}$ & $\begin{array}{l}\text { [iyon] } \\
\text { [bi }{ }^{\mathrm{y}} \text { odata] }\end{array}$ \\
\hline 5 & ea & Idealis & [ideyalis] \\
\hline 6 & eo & $\begin{array}{l}\text { Geometri } \\
\text { Beo }\end{array}$ & $\begin{array}{l}\text { [ge } \mathrm{gemetri]}^{\mathrm{y}} \\
{\left[\mathrm{be}^{\mathrm{y}} \mathrm{o}\right]}\end{array}$ \\
\hline
\end{tabular}

Table 2. The Distribution of the Insertion of [y]

The semivowels $[y]$ are placed between the diphthongs ia, iu, ie, io, ea, and eo based on the data. For example, [y] appears between [i] and [a] to get [i\{y\}a]. It may be deduced from the data that $[\mathrm{y}]$ always comes after [i]. The distributions of $[\mathrm{y}]$ can be writtern as follows.

[y] / [i] $-[\mathrm{a}]$

$[\mathrm{y}] /[\mathrm{i}]-[\mathrm{u}]$

$[\mathrm{y}] /[\mathrm{i}]-[\mathrm{e}]$

$[\mathrm{y}] /[\mathrm{i}]-[\mathrm{o}]$

[y] / [e] $-[\mathrm{a}]$

$[y] /[e]-[o]$

\section{The Phonological Rules of The Insertion of [y]}

1. There is a sound insertion of [y] to separate the vocal groups [i] and [a], [i] and [u], [i] and [e], and [i] and [o]. Thus, it can be written that the insertion of [y] always appears after [i]. Based on Schane (1992), the sentence can be written through the phonological rules below.

$\varnothing$ ? [y]/[i]

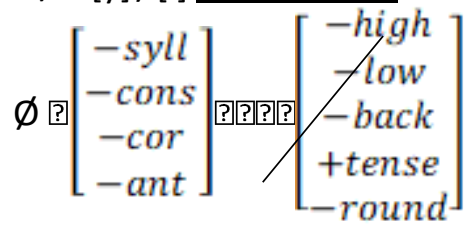

\section{[-high]}

2. There is a sound insertion [w] to separate the vocal groups [o] and [a], [o] and [e]. Therefore, it can be written that the insertion of [w] always appears after [o] and then is followed by vowel. The sentence can be written through the phonological rulesbelow.

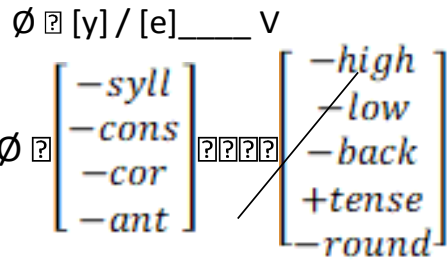

\section{$[-h i g h]$}

This rule explains that the insertion of semivowels [y] appears between the vowel 
sounds [-back] and it is followed by other vowel sounds. The vowel [-back] that can be categorized as [i] and [e] produce sounds by giving the front position of our tongue. Therefore, [y] has the possibility to insert and appear after [-back] because it is determined by the location of the tongue's position when making sounds. The position of the tongue when we make [i] and [e] sounds has a great similarity when we produce [y] sounds. Then, the insertion of [y] appears after [e] and is followed by vowels that has distinctive [-high].

The spectrogram below shows that there is a vibration between [e] and [o] from the word beo. It can be proved that there is a pause after [e] which is the insertion of [y]. It can be seen from the second $1.000-1.100$.

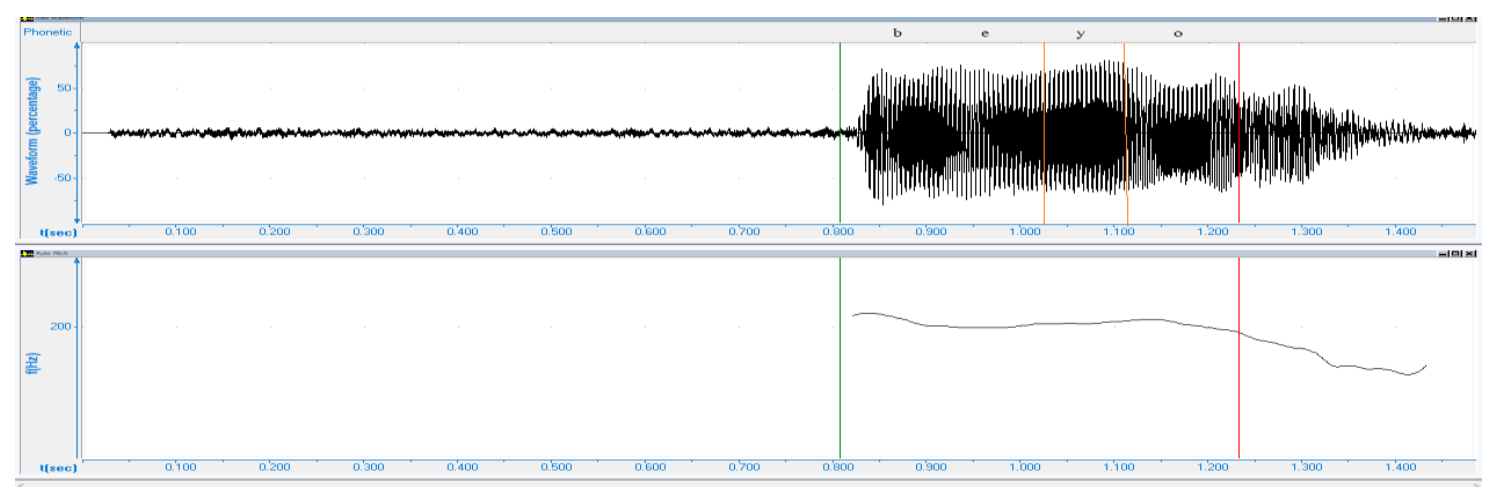

Picture 1. The Spectogram of the Appearance of [y]

\subsection{The Insertion of $[w]$}

The semivowel $[\mathrm{w}]$ is inserted between the diphthongs $u a, u i, u e, u o, o a$, and oe. The semivowel $[\mathrm{w}]$ appears between $[\mathrm{u}]$ and [a]. Thus, it becomes [ $\left.\mathrm{u}^{\mathrm{w}} \mathrm{a}\right]$. To make it clear, the distributions of $[\mathrm{w}]$ are presented through the table below.

\begin{tabular}{|c|c|c|c|}
\hline \multicolumn{4}{|c|}{ The Insertion of [w] } \\
\hline No & Diphthongs & Examples & Phonetic Transcriptions \\
\hline 1 & ua & $\begin{array}{l}\text { Benua } \\
\text { Dua }\end{array}$ & $\begin{array}{l}\text { [benuwa] } \\
{\left[\text { duwa }^{w} a\right]}\end{array}$ \\
\hline 2 & ui & $\begin{array}{l}\text { Buih } \\
\text { Konduite }\end{array}$ & $\begin{array}{l}{\left[\mathrm{bu}^{\mathrm{w}} \mathrm{ih}\right]} \\
{\left[\mathrm{kondu}^{\mathrm{w}} \mathrm{it}\right]}\end{array}$ \\
\hline 3 & ue & Duet & {$\left[\mathrm{du} \mathrm{w}^{\mathrm{w}} \mathrm{et}\right]$} \\
\hline 4 & no & $\begin{array}{l}\text { Kuota } \\
\text { Kuorum }\end{array}$ & $\begin{array}{l}\text { [kuwota] } \\
\text { [kuworum] }\end{array}$ \\
\hline 5 & oa & Oasis & [owasis] \\
\hline 6 & oe & Oedipus kompleks & [owdipus kompleks] \\
\hline
\end{tabular}

Table 3. The Distribution of the Insertion of [w]

Meanwhile, the distributions of [w] can be written as follows.

$[\mathrm{w}] /[\mathrm{u}]-[\mathrm{a}]$

$[\mathrm{w}] /[\mathrm{u}]-[\mathrm{i}]$

$[\mathrm{w}] /[\mathrm{u}]-[\mathrm{e}]$

$[\mathrm{w}] /[\mathrm{u}]-[\mathrm{o}]$

$[\mathrm{w}] /[\mathrm{o}]-[\mathrm{a}]$

$[\mathrm{w}] /[\mathrm{o}]-[\mathrm{e}]$

\section{The Phonological Rules of the Insertion of [w]}

1. There is a sound insertion $[\mathrm{w}]$ to separate the vocal groups $[\mathrm{u}]$ and $[\mathrm{a}],[\mathrm{u}]$ and $[\mathrm{i}],[\mathrm{u}]$ and 
$[e]$, and $[u]$ and [o]. Thus, it can be written that the insertion of [w] always appears after [u]. Based on Schane (1992), the sentence can be written through the phonological rules below.

$\varnothing$ ? $[\mathrm{w}] /[\mathrm{u}]$
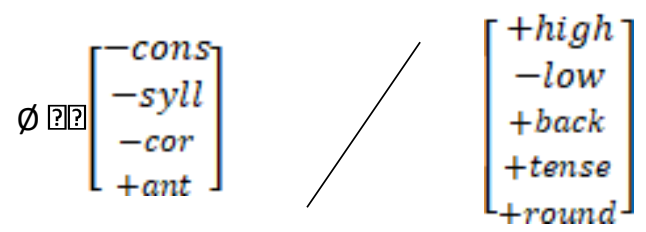

2. There is a sound insertion [w] to separate the vocal groups [o] and [a], [o] and [e]. Therefore, it can be written that the insertion of [w] always appears after [o] and then is followed by a vowel. The sentence can be written through the phonological rules below.

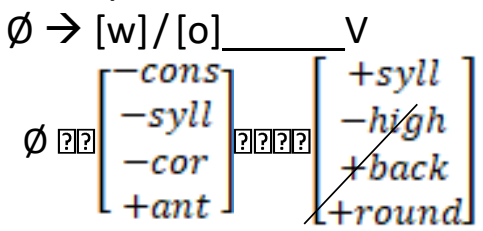

$$
\left[\begin{array}{c}
- \text { high } \\
\text { +tense } \\
- \text { round }
\end{array}\right]
$$

This rule explains that the semivowel $[\mathrm{w}]$ appears between the vowel and vowel sounds. The insertion of semivowels [w] results from the influence of vowel sounds with distinctive characteristics [+ back] which are contained in [u] and [o]. It is an evident from the distribution of $[\mathrm{w}]$ that $[\mathrm{w}]$ always appears after [u] and is followed by all vowels such as [a], [i], [e], and [o], whereas [u] does not appear because Indonesian has no double vowels for one word. Then, the insertion of [w] also appears between [o] followed by vowel [a] and [e] where the vowel has the same characteristics namely [-high], [+ tense], and [-round].

One of the characteristics of back-vocal sounds is the vowel sound that is marked by the retraction of the tongue's body to the back to the palatal cavity, namely [u], [o], and [0]. Thus, it can be concluded that the appearance of the sound [w] is influenced by the sound [u] and sound [o] as the back vowel.

This spectrogram proves the evidence that $[\mathrm{w}]$ appears between $[\mathrm{u}]$ and [a]. Thus, Indonesian people read the written text dua becomes [duwa]. It can be seen in seconds 0.900-1.000

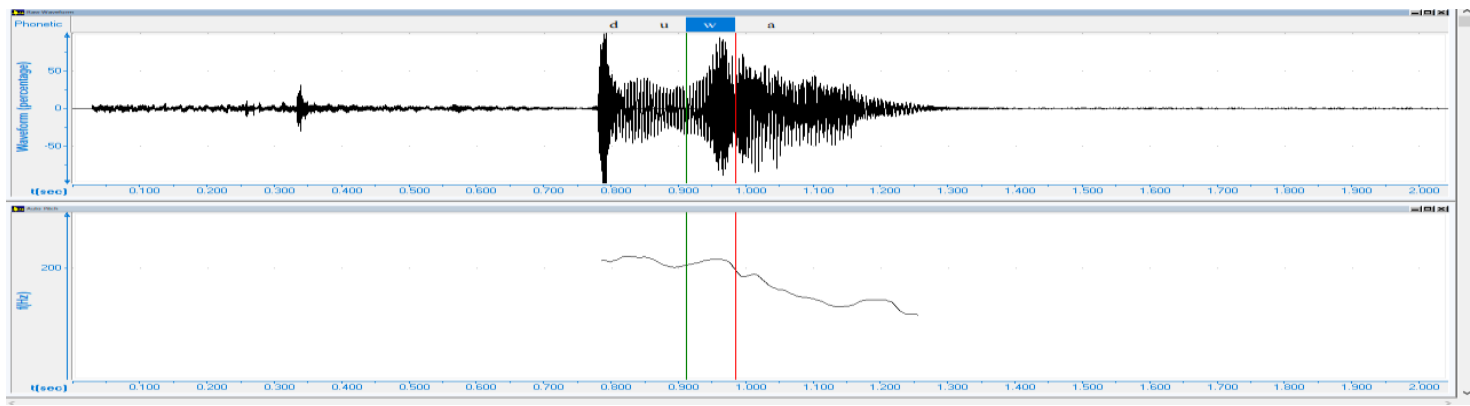

Picture 2. The Spectogram of the Appearance of [w]

\subsection{No Insertion both $[y]$ and [w]}

\begin{tabular}{|c|l|l|l|}
\hline \multicolumn{3}{|c|}{ No Insertion both [y] and [w] } \\
\hline No & Diphthongs & \multicolumn{1}{|c|}{ Examples } & Phonetic Transcriptions \\
\hline 1 & ai & Lantai & {$[$ lantay] } \\
\hline 2 & au & Kalau & {$[$ kalaw] } \\
\hline
\end{tabular}




\begin{tabular}{|c|l|l|l|}
\hline 3 & ae & $\begin{array}{l}\text { Aerobik } \\
\text { Aerosol }\end{array}$ & $\begin{array}{l}{[\text { aerobik] }} \\
\text { [aerosol] }\end{array}$ \\
\hline 4 & ao & Aorta & {$[$ aorta] } \\
\hline 5 & ei & $\begin{array}{l}\text { Eigendom } \\
\text { Mei }\end{array}$ & $\begin{array}{l}\text { [eigendom] } \\
{[\text { mei] }}\end{array}$ \\
\hline 6 & eu & Eufili & {$[$ eufili] } \\
\hline 7 & oi & $\begin{array}{l}\text { Koboi } \\
\text { Amboi }\end{array}$ & $\begin{array}{l}\text { [koboy] } \\
\text { [amboy] }\end{array}$ \\
\hline 8 & ou & Voucer & [vocer] \\
\hline
\end{tabular}

Table 4. No Insertion both [y] and [w]

The insertion of $[\mathrm{y}]$ and $[\mathrm{w}]$ does not appear when meeting with diphthong ai, $a u, a e$, $a o, e i, e u, o i$, and ou. It happens because there are rules that $[\mathrm{y}]$ and $[\mathrm{w}]$ cannot insert between [a] and [i] or [u]. This is evidenced by the fact that people in Indonesia do not pronounce [lanta $\mathrm{y}_{\mathrm{i}}$ ] or [lanta $\mathrm{w}_{\mathrm{i}}$ ] in their daily communication. Then, $[\mathrm{y}]$ and [w] do not appear in diphthong ae, ao, ei, eu, oi, ou because the majority of that words are adapted from some foreign languages that should be pronounced similar to the pronunciation in their respective languages.

The spectrogram below shows that diphthong ei or [i] behind the consonant is not obliterated from the word Mei. It proves that the diagram is presented in full in one word. It can be seen from the seconds $0.600-1.000$.

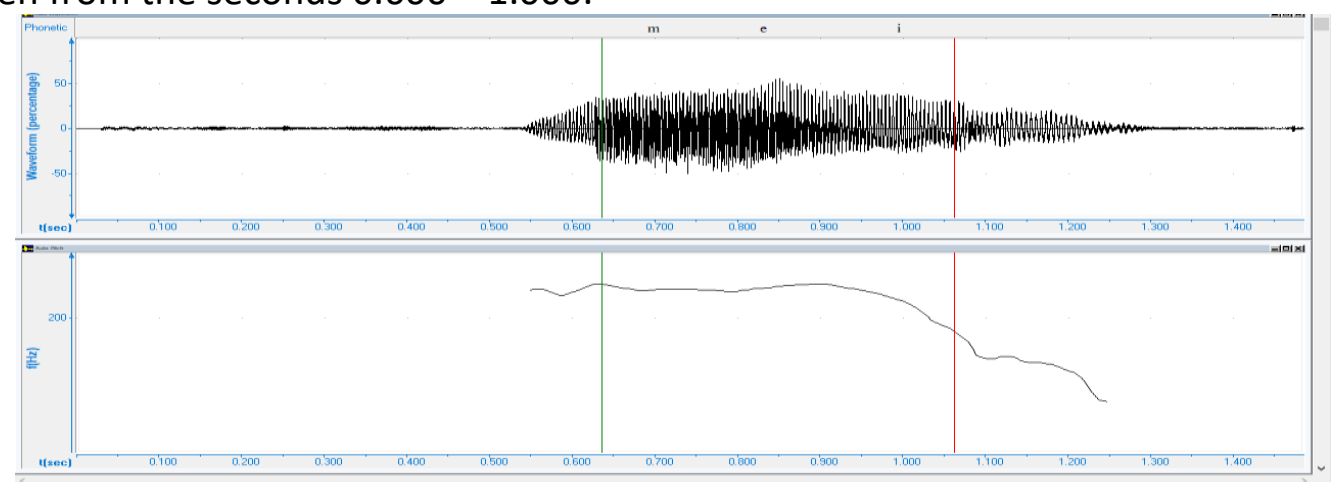

Picture 3. The Spectogram of the Obliteration of $[\mathrm{y}]$ and $[\mathrm{w}]$

\subsection{Special Case in Semivowels}

\begin{tabular}{|c|l|l|l|}
\hline \multicolumn{4}{|c|}{ Special Case } \\
\hline No & Diphthongs & \multicolumn{1}{|c|}{ Examples } & \multicolumn{1}{c|}{ Phonetic Transcriptions } \\
\hline 1 & aa & Kendaraan & {$[$ kəndara?an $]$} \\
\hline 2 & oa & $\begin{array}{l}\text { Doa } \\
\text { Soal }\end{array}$ & $\begin{array}{l}{[\text { do?a] }} \\
{[\text { so?al] }}\end{array}$ \\
\hline 3 & ei & Survei & {$[$ surve] } \\
\hline
\end{tabular}

Table 5. Special Case in Semivowels

In this particular case, one word has been found with the same double vowel aa and oa. The phonetic transcription indicates that there is a glottal stop ( $P$ ) in [kəndara?an] and [do?a]. Glottal stop makes us to close our vocal cords as we hold our breath. When it's opened, then we will continue to produce [a]. Therefore, it makes both [w] and [y] do not appear in the pronunciation process. Meanwhile, the [i] in the word survei is not clearly pronounced or even tend to disappear. This might be due to the adaptation of the word survey [s3rve!] in 
English which was changed into Indonesian into a survey where the pronunciation prefers to remove [i] which then becomes similar to how to read in English and makes it more acceptable in pronunciation and meaning in Bahasa Indonesia rather than the insertion of $[\mathrm{w}]$ and $[\mathrm{y}]$ become $\left[\right.$ surve $\left.^{\mathrm{w}} \mathrm{i}\right]$ or [surve ${ }^{\mathrm{y}_{\mathrm{i}}}$.

This spectrogram gives evidence that there is a space between [o] and [a] when we pronounce the word soal. This is the space of glottal stop [?] or we can blank space starts from 0.600 until 0.800 .

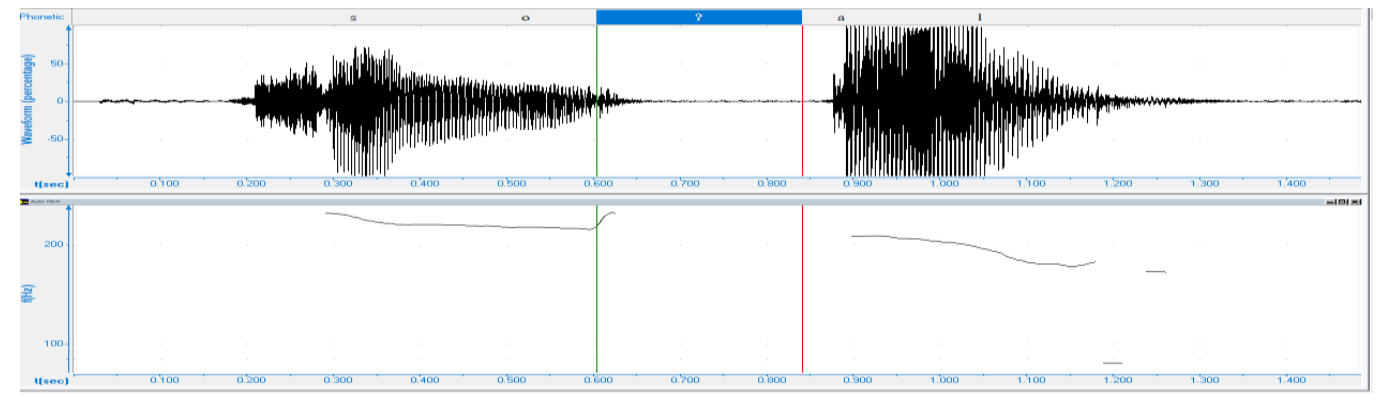

Picture 4. The Spectogram of the Appearance of the Glottal Stop

\section{Conclusion}

The discussion above can be concluded into three parts. First, the semivowel [y] is inserted between the diphthongs $i a, i u, i e, i o, e a$, and eo. Thus, [y] always appears after [i] and some in [e] that are followed by [-high] vowels. Second, the semivowel [w] is inserted between the diphthongs $u a, u i, u e, u o, o a$, and oe. It can be concluded that $[\mathrm{w}]$ always appears after $[\mathrm{u}]$ and some in [o] that followed by [-high], [+tense], [-round] vowels. Meanwhile, the insertion of [y] and [w] does not appear when meeting with diphthong $a i$, $a u, a e, a o, e i, e u, o i, o u$. This study also finds two special cases where diphthongs $a a$ and oa can appear with a glottal stop so that $[y]$ and $[w]$ do not appear. Then, there is a deletion of [i] sound in the word survei that caused of borrowing word from another language. The spectrograms that are included in the discussion have a function to show the location of the insertion of $[\mathrm{y}]$ and $[\mathrm{w}]$ in Bahasa Indonesia's words taken from KBBI.

\section{References}

Arifiani, E. \& Subiyanto, A. (2019). Sistem perubahan struktur silabel dan netralisasi vokal dalam bahasa sasak dialek bayan. Jurnal Jalabahasa, 15 (1), 36-47.

Ary, D., Jacobs, L. C., Sorensen, C., \& Razafieh, A. (2010). Introduction to Research in Education ( $8^{\text {th }}$ edition). Belmont: Wadsworth Cengage Learning.

Chomsky, N., \& Halle M. (1968). The sound pattern of English. New York: the United States of America.

Erawati, N. K. R. (2017). Interpretasi segmen bunyi bahasa jawa kuno: Analisis speech analyzer dan fitur distingtif. Jurnal Aksara, 29 (2), 225-238.

Schane, F. A. (1992). Fonologi generatif. Jakarta: PT. Gelora Aksara Pratama.

Subroto, E. (2007). Pengantar Metode Penelitian Linguistik Struktural. Surakarta: Universitas Sebelas Maret Press.

Sugiyono. (2014). Metode Penelitian Pendidikan Pendekatan Kuantitatif, Kualitatif, dan R\&D. Bandung: Alfabeta.

Swadana, W. I. (2018). Fonologi bahasa Bali dialek jembrana. Jurnal IImu Sosial Humaniora, 7 (1), $77-86$ 